\title{
Farm systems - Impact of stocking rate on dairy farm efficiency
}

\author{
K.A. MACDONALD, J.W. PENNO, P.K. NICHOLAS, J.A. LILE, M. COULTER \\ and J.A.S. LANCASTER \\ Dexcel, Private Bag 3123, Hamilton \\ kevin.macdonald@dexcel.co.nz
}

\begin{abstract}
Two years of results from a 10 farmlet, farm systems trial (ending May 2001) are presented. The trial was designed to determine the efficiency and profitability of milksolids production when annual drymatter intake/cow and subsequent milksolids production/cow is increased within a whole farm system. Operating within the trial were five levels of feed intake and two farm management systems.

The data presented show that with increasing $\mathrm{kg}$ liveweight/tonne of drymatter/ha, there was an increase in efficiency of pasture utilisation but a decrease in per cow efficiency. Extremes in increasing $\mathrm{kg}$ liveweight/tonne of drymatter were inclined to decrease the Economic Farm Surplus.
\end{abstract}

Keywords: allowance, dairying, efficiency, milksolids, model

\section{Introduction}

The efficiency of milk production from pasture is a function of annual pasture production, the efficiency of pasture utilisation, and the efficiency of milksolids production per cow (Holmes \& Macmillan 1982; Penno 1999). Annual pasture production determines the total amount of feed energy available for animal maintenance, growth and milk production and therefore provides the ultimate limit to the amount of milk yield that can be produced from grazed pasture. However, it is also generally accepted that the high genetic merit cow presents an opportunity to substantially improve production per cow (Penno \& Kolver 2000). Although the majority of research in recent years has continued at high stocking rates, some recent research has suggested that profitability may be increased by reducing stocking rate (McCall \& Clark 1998).

In 1955, over $90 \%$ of LIC inseminations were of Jersey semen. By the early 1990s, this had decreased to less than $30 \%$ with Holstein-Friesian increasing to over 70\% (LIC 1999). Also, from 1979 to 2000, the average New Zealand stocking rate (SR) increased from 2.1 to 2.7 cows/ha (LIC 1999) as a way to increase whole farm efficiency. As a consequence of these changes there has been a major change in the $\mathrm{kg}$ of liveweight/ ha on New Zealand dairy farms. As an example, from 1979 to 1993 the average post-calving liveweight of the cows at Dexcel's, No. 2 Dairy increased from 390 to $460 \mathrm{~kg}$. The combined effect of the increased cow numbers/ha and heavier cows has led to a large increase in the total liveweight farmed per ha.

We define whole farm efficiency as determined by the total amount of feed available, the proportion of the available feed that is eaten (feed utilisation), and the proportion of consumed feed that contributes directly to milk production (milk production efficiency). Yet, analysis of economic farm surplus (EFS) has demonstrated that farms with similar EFSs may have big differences in per cow and per hectare productions (Deane 1993). This may be because many of the variable costs incurred are directly related to the number of cows milked and the SR at which EFS is optimised is generally lower than that required for optimum milksolids (MS) production. McCall \& Clark (1998) and Penno (1998) demonstrated that high EFS can be achieved at a low SR as long as this allows the cows to achieve high MS per cow. Practical limitations to the number of cows that may be farmed (such as labour requirements and farm dairy shed size) and to increasing feeding levels, could be reasons to lower SR.

This research (which ran for 3 years) was designed to quantify the change in efficiency and profitability of MS production when annual dry matter intake (DMI)/ cow is increased within a whole farm system by reducing $\mathrm{kg} \mathrm{LWT/t} \mathrm{DM.}$

\section{Materials and methods}

Ten farmlet systems were established at the Dexcel's No 2 Dairy at Hamilton, New Zealand in July 1998. Each farmlet was balanced for geographic location, soil type, and previous treatments. Farmlets had $200 \mathrm{~kg}$ $\mathrm{N} /$ ha applied annually with an expected annual pasture production of $18.0 \mathrm{t} \mathrm{DM} / \mathrm{ha}$ (McGrath et al. 1998). Owing to another trial already in place at No. 2 Dairy, the Whole Farm Efficiency trial was not set up until late-July 1998 after the cows had started calving. Average pasture cover was low (1530 Kg DM/ha) and hence cow DMI was compromised. This had a major impact on cow MS production in early spring and for 
that reason, only the second two seasons will be described in this paper.

Total annual feed allowances of approximately 8.1, $6.8,5.8,4.9$ and $4.2 \mathrm{t} \mathrm{DM} / \mathrm{cow} /$ year were created by stocking the farmlet systems with $500 \mathrm{~kg}$ HolsteinFriesian cows of high genetic merit at a target of 62 , 76, 90103 and $120 \mathrm{~kg} \mathrm{LWT/t} \mathrm{DM/year} \mathrm{(Table} \mathrm{1).}$ There were two replicates at each level of target $\mathrm{kg}$ LWT/t DM. The cows were of mixed age with $20 \%$ replaced annually. The groups of cows were balanced for age, calving date, genetic merit, liveweight and previous treatment.

Table 1 Experimental details of the Whole Farm Efficiency trial (June 1999 to May 2001).

\begin{tabular}{lccccc}
\hline $\begin{array}{l}\text { Farmlet } \\
\text { number }\end{array}$ & $\begin{array}{c}\text { Target } \\
\text { (kg Lw/t DM) }\end{array}$ & $\begin{array}{c}\text { Stocking rate } \\
\text { (cows/ha) }\end{array}$ & $\begin{array}{c}\text { Farmlet size } \\
\text { (paddocks) }\end{array}$ & $\begin{array}{c}\text { Farmlet size } \\
\text { (ha) }\end{array}$ & $\begin{array}{c}\text { Herd size } \\
\text { (cows) }\end{array}$ \\
\hline $1 \& 6$ & 62 & 2.2 & 20 & 8.1 & 18 \\
$2 \& 7$ & 76 & 2.7 & 18 & 7.3 & 20 \\
$3 \& 8$ & 90 & 3.2 & 15 & 6.1 & 19 \\
$4 \& 9$ & 103 & 3.7 & 12 & 4.9 & 18 \\
$5 \& 10$ & 120 & 4.3 & 11 & 4.5 & 19 \\
\hline
\end{tabular}

One replicate ("DR") at each level of annual feed allowance was randomly allocated to current decision rules for high stocked dairy systems (Macdonald \& Penno 1998). Decision rules for the second series of farmlets ("SM") were derived from UDDER (Larcombe 1994), a computer simulation model. Management variables available for manipulation were, daily allowance of pasture and pasture silage, the area and timing of pasture conservation, and the timing of culling and drying off. Net herbage accumulation, average herbage mass, pre- and post-grazing herbage mass, DMI, MS yield, along with cow condition score and LWT were measured fortnightly and applied to each decision making protocol.

\section{Management}

The DR farmlets were managed according to a set of decision rules established by Macdonald \& Penno (1998) which uses weekly assessments of farm cover (kg DM/ha). Following this assessment, decisions on management were made for the next week, taking into account amongst other things, current farm cover, expected pasture growth, cow condition and season of the year.

Actual data for the SM farmlets were entered into UDDER on a fortnightly basis, then repeat computer simulations were then run for each SM farmlet to investigate possible management strategies. The strategy demonstrating the most profitable outcome for the remainder of the season was then implemented within the respective farmlet system over the next 2 weeks.

\section{Measurements}

Pasture mass was estimated by calibrated visual assessment of each paddock from a weekly farm walk. On each occasion, 11 calibration quadrats (each $0.3 \mathrm{~m}^{2}$ ) covering the range of herbage mass present were set out. These quadrats were assessed pre- and post-farm walk. After the final assessment the quadrats were cut to ground level, washed and dried in a forced draught oven at $95-100^{\circ} \mathrm{C}$ for $48 \mathrm{hr}$. The herbage mass estimate for each paddock was then adjusted using a regression of quadrat visual assessment on quadrat herbage mass. The net herbage accumulation was calculated weekly from the increase in herbage mass on ungrazed paddocks. Average herbage mass was calculated from the weekly estimates of herbage mass of each paddock. Pasture DMI of each group was calculated by disappearance based on pre-and post-grazing herbage masses estimated on 3 successive days of each week.

Pasture samples were hand clipped to grazing height from the grazing area of each treatment group monthly. Samples were oven dried at $60^{\circ} \mathrm{C}$, ground and analysed for chemical composition by NIRS (Ulyatt et al. 1995).

Milk volume and composition (milk fat, protein, and lactose) of all cows was measured by weekly herd test. Tru-test in-line milk meters were used to take a representative sub-sample of $2.5 \%$ of the total milk yield of each cow. A sub-sample, representative of the morning and afternoon milk, was analysed to determine fat, protein and lactose content by calibrated Fossomatic FT120 (Foss Electric, Hellorod, Denmark).

Liveweight and condition score of each cow was recorded fortnightly immediately after morning milking. Liveweight was measured by using Tru-test electronic scales and condition score was visually assessed according to Dexcel Farm Facts 1-1.

Economic farm surplus was calculated using Dexcel Farms Fact 7-3. Average costs for a New Zealand dairy farm (LIC 2000) were used except for what could be possibly related to a treatment effect. These were the use of CIDRs ( $\$ 25 / \mathrm{cow}$ ) on anoestrum cows and topping for removal of surplus pasture ( $\$ 40 / \mathrm{ha}$ ). Harvesting of silage was costed at $20 \mathrm{c} / \mathrm{kg} \mathrm{DM}$ and any that was not fed back to a treatment was sold from that treatment at its harvesting price. Milksolids was priced at $\$ 4.50 / \mathrm{kg}$.

\section{Results}

Although there were large differences in management between the DR and SM farmlets (such as amount of conservation, grazing interval and area topped) there 
were only small differences in annual MS production $(<6 \%)$ and EFS $(<8 \%)$. For this reason the data presented is for the $\mathrm{kg} \mathrm{LWT/t} \mathrm{DM} \mathrm{treatments} \mathrm{and} \mathrm{no}$ comparison is made between DR and SM.

Net herbage accumulation and pasture quality increased with increasing $\mathrm{kg} \mathrm{LWT} / \mathrm{t} \mathrm{DM}$, and were closely associated with an increase in pasture consumption (Table 2). As stocking rate increased, pasture consumption per cow declined from 56563 MJME/cow/year at $62 \mathrm{~kg} \mathrm{LWT} / \mathrm{t} \mathrm{DM}$ to 43388 megajoules of metabolisable energy (MJME)/cow/year at $120 \mathrm{~kg} \mathrm{LWT} / \mathrm{t} \mathrm{DM}$.

With decreasing $\mathrm{kg}$ LWT/t DM there was an increased amount of topping and pasture conservation (Table 3). The lowest $\mathrm{kg} \mathrm{LWT/t} \mathrm{DM} \mathrm{farmlets} \mathrm{were}$ topped 2.1 times and $702 \mathrm{~kg} \mathrm{DM} / \mathrm{cow}$ was conserved as silage compared with no topping $(\mathrm{P}<0.017)$ and little pasture conservation $(\mathrm{P}<0.002)$ at the highest. At the low kg LWT/t DM, only $237 \mathrm{~kg}$ $\mathrm{DM} /$ cow of the conserved feed was offered back to the herd.

Pasture utilisation increased as $\mathrm{kg}$ LWT/t DM increased from 62 to 103 $(\mathrm{P}<0.001)$. However, a further increase (to $120 \mathrm{~kg} \mathrm{LWT} / \mathrm{t} \mathrm{DM}$ ) did not increase utilisation. Also, as kg LWT/t DM increased, milksolids yield per cow declined, the efficiency of pasture utilisation increased, but per cow efficiency decreased (ME in milk/ME eaten). However, the loss in efficiency associated with decreasing milk yields was sufficient to cancel out the increased efficiency of pasture utilisation. Total efficiency, as calculated by ME in milk/total ME supply, did not alter $(\mathrm{P}<0.105)$ with increasing $\mathrm{kg} \mathrm{LWT} / \mathrm{t}$ DM (Figure 1). The drop off in production per cow with increasing $\mathrm{kg}$ LWT/t DM and the inverse of MS/ha was consistent (Figure 2).

Initial cow LWT across all treatments was $500 \mathrm{~kg}$. The cows on the $120 \mathrm{~kg} \mathrm{LWT} / \mathrm{t}$ DM farmlets were $40 \mathrm{~kg}$ lighter than those on the $62 \mathrm{~kg} \mathrm{LWT} / \mathrm{t} \mathrm{DM}$

Table $\llbracket 2$ Estimates of net herbage accumulation, pasture quality and ME consumption at different target $\mathrm{kg}$ LWT/t DM.

\begin{tabular}{lcccccc}
\hline Target kg LWT/t DM & 62 & 76 & 90 & 103 & 120 & SED \\
\hline $\begin{array}{c}\text { Net herbage accumulation } \\
\text { (t DM/ha/year) }\end{array}$ & 17.5 & 17.9 & 18.8 & 18.3 & 19.8 & 0.417 \\
$\begin{array}{c}\text { Pasture quality } \\
\text { (MJME/kg DM). }\end{array}$ & 11.3 & 11.4 & 11.5 & 11.6 & 11.6 & 0.107 \\
$\begin{array}{c}\text { Pasture consumption } \\
\text { (MJME/ha/year) }\end{array}$ & 125795 & 143025 & 155892 & 172290 & 185179 & 1553 \\
\hline
\end{tabular}

Table $\ 3$ The effect of stocking rate on lactation length, annual milksolids yield per cow and per hectare, the amount of pasture conservation and topping, and estimated economic farm surplus (EFS).

\begin{tabular}{|c|c|c|c|c|c|c|}
\hline Target kg LWT/t DM & 62 & 76 & 90 & 103 & 120 & SED \\
\hline Days in milk & 296 & 278 & 260 & 238 & 222 & 4.3 \\
\hline kg MS/cow & 435 & 380 & 353 & 309 & 274 & 7.5 \\
\hline $\mathrm{kg} \mathrm{MS} / \mathrm{ha}$ & 967 & 1043 & 1105 & 1145 & 1168 & 19.0 \\
\hline Silage made $\mathrm{kg} \mathrm{DM} / \mathrm{cow}$ & 702 & 509 & 293 & 99 & 23 & 113.8 \\
\hline$\%$ of farm topped & 210 & 100 & 40 & 10 & 0 & 58.1 \\
\hline EFS $\$ / h a^{*}$ & 2884 & 2960 & 3054 & 2940 & 2751 & 73.6 \\
\hline EFS \$/ha (capital cost included) & 2661 & 2686 & 2741 & 2570 & 2325 & 73.6 \\
\hline Liveweight at 30 May, at end of trial (kg/cow). & 489 & 475 & 472 & 467 & 448 & 6.2 \\
\hline
\end{tabular}

* EFS-Economic Farm surplus calculated at $\$ 4.50 / \mathrm{kg} \mathrm{MS}$

Figure $\llbracket 1$ The effect of stocking rate on the efficiency of pasture utilisation, the gross efficiency of milk production and the efficiency of the whole farm system.

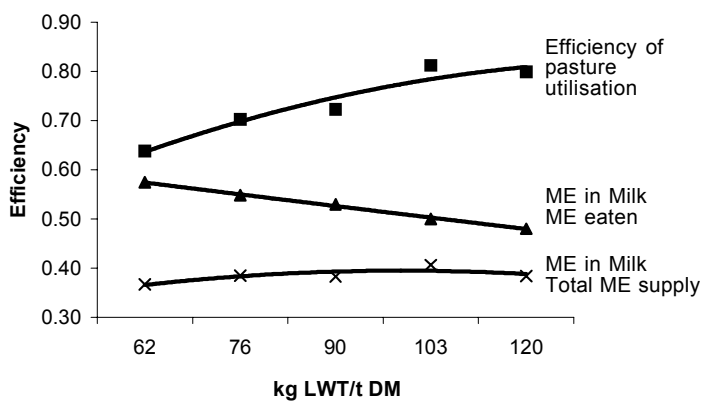

Figure $\llbracket 2$ The effect of stocking rate (based on annual net herbage accumulation of $18 \mathrm{t} \mathrm{DM} / \mathrm{ha} / \mathrm{year}$ ) on milksolids yield per cow and per hectare.

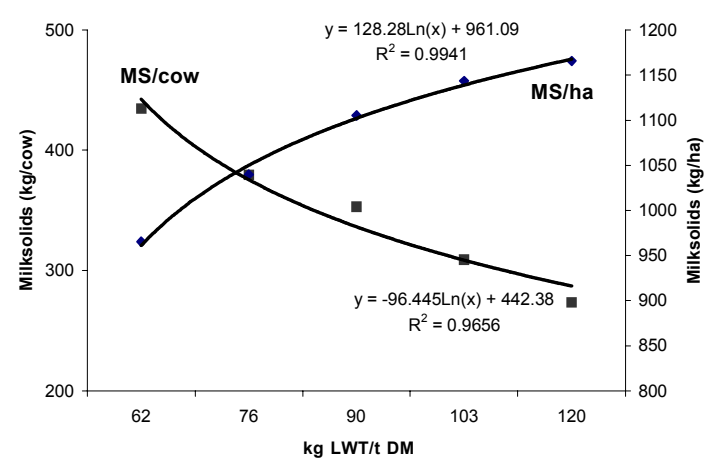


farmlets at the start of year $3(2000 / 2001)$. This difference had increased at the end of the trial (Table 3) to nearly $60 \mathrm{~kg}$ (30 May 2001).

If the capital cost of cows ( $\$ 100 / \mathrm{cow})$ is included in EFS calculations, it has the effect of altering the EFS so that the difference between the lowest kg LWT/ t DM treatment and the optimum (for EFS) is reduced to only $\$ 40$, whereas with highest LWT/t DM it is increased by $\$ 113$ (Table 3). This is solely a reflection of the extra capital cost associated with increased cow numbers.

\section{Discussion}

For the last 50 years there has been a strong emphasis on increasing stocking rate as a means of increasing pasture utilisation (McMeekan 1950; Bryant 1990). These authors reported that increasing pasture utilisation by increasing SR would increase total milksolids production, with the assumption farm profitability would also increase.

Our results showed that as $\mathrm{kg}$ LWT/t DM increased, the efficiency of feed utilisation also increased while individual cows ate less. Simultaneously, as each cow ate less her annual milk yield declined and an increasing proportion of the feed eaten was used for maintenance and pregnancy thus reducing the gross efficiency of milk production. The results showed that efficiency of pasture utilisation increased with increasing $\mathrm{kg}$ LWT/t DM but there was a decrease in efficiency per cow (Figure 1). In contrast to early SR studies (Holmes \& Macmillan 1982), the loss in efficiency associated with decreasing MS production per cow was sufficient to cancel out the increase of pasture production so that the whole farm efficiency changed little with SR.

In this trial with increasing $\mathrm{kg} \mathrm{LWT} / \mathrm{t} \mathrm{DM}$, there was a decline in per cow production with reasonably high per cow MS being achieved (from 274 to $435 \mathrm{~kg}$ $\mathrm{MS} / \mathrm{cow})$. The highest EFS was achieved at $90 \mathrm{~kg}$ $\mathrm{LWT} / \mathrm{t} \mathrm{DM} / \mathrm{ha}$. At the extremes of the treatments there were differences in EFS of 5.6 and $9.9 \%$ /ha for the 62 and $120 \mathrm{~kg} \mathrm{LWT} / \mathrm{t} \mathrm{DM} /$ farmlets, respectively (Table 3 ). Normally EFS is calculated without regard to the capital cost associated with the number of cows farmed. Including the capital cost of farming, the extra cows can have a big impact on the EFS of high SRs. In this trial, decreasing kg LWT/t DM had less of an effect on EFS than increasing it. As many of the costs in calculating an EFS are associated with the number of cows farmed, thus higher SR farmlets can be at a disadvantage. The differences in EFS between treatments were relatively small considering the wide range in per cow and per ha MS production. This clearly shows that there is room for a reduction in SR without a great affect on EFS.

\section{Conclusion}

Our trial demonstrated that efficiency of pasture utilisation increased with LWT/t DM. The combined effect of this was that whole farm efficiency changed little with changing $\mathrm{kg} \mathrm{LWT/t}$ DM. Optimum EFS occurred at less than maximum feed efficiency.

\section{REFERENCES}

Bryant, A.M. 1990. Present and future grazing systems. Proceedings of the New Zealand Society of Animal Production 50: 35-38.

Deane, T.H. 1993. The relationship between milkfat production per hectare and economic farm surplus on New Zealand dairy farms. Proceedings of the New Zealand Society of Animal Production 53: 51-53.

Dexcel Farm Facts. 2001. Cow body condition scoring. Dexcel Ltd, Hamilton New Zealand: 1-1

Dexcel Farm Facts. 2001. Economic farm surplus. Dexcel Ltd, Hamilton, New Zealand: 7-3.

Larcombe, M.T. 1994. UDDER 8: A Desktop Dairy Farm for Extension and Research - Operating Manual. Maffra Herd Improvement Co-op, Maffra, Vic, Australia.

Holmes, C.W.; Macmillan, K.L. 1982. Nutritional management of the dairy herd grazing on pasture. pp. 244-274. In: Dairy production from pasture. Proceedings of the New Zealand and Australian Societies of Animal Production. Eds. Macmillan KL; Taufa VK, Hamilton, New Zealand. 244-274.

LIC 1999. Dairy Statistics 1999/2000. Livestock Improvement Corporation Ltd, Hamilton, New Zealand.

LIC 1999. Economic Survey of New Zealand Dairy Farmers. 1999/2000. Livestock Improvement Corporation Ltd, Hamilton, New Zealand.

McCall, D.G.; Clark, D.A. 1998. Optimised dairy grazing systems in the Northeast USA and New Zealand. II. System analysis. Journal of Dairy Science 82: 1808-1816.

Macdonald, K.A.; Penno, J.W. 1998. Management decision rules to optimise milksolids production on dairy farms. Proceedings of the New Zealand Society of Animal Production 58: 132-135.

McGrath, J.M.; Penno, J.W.; Macdonald, K.A.; Carter, W.A. 1998. Using nitrogen to increase dairy farm profitability. Proceedings of the New Zealand Society of Animal Production 58: 117-120. 
McMeekan, J.P. 1950. Recommended techniques in dairy farming. Proceedings of the Ruakura Farmers' Conference 2: 184-193.

Penno, J.W. 1998. Principles of profitable dairying. Proceedings of the Ruakura Farmers' Conference 50: $1-14$.

Penno, J.W. 1999. Stocking rate for optimum profit. Proceedings of the South Island Dairy Event 1: 25-43.

Penno, J.W.; Kolver, E.S. 2000. Future farm systems. Proceedings of the Ruakura Farmers' Conference 52: 3-13.

Ulyatt, M.J.; Lee, J.; Corson, D. 1995. Assessing feed quality. Proceedings of the Ruakura Farmers' Conference 47: 59-62. 